\title{
Dichrocephala integrifolia (Astereae, Asteraceae), a new exotic genus and SPECies for Mexico and second ReCord for the NeW World

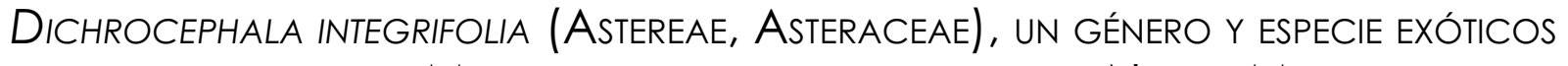 nuevos para México y Segundo registro para el Nuevo Mundo
}

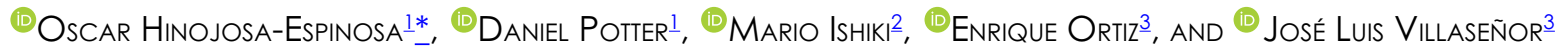

\author{
' Department of Plant Sciences, University of California, Davis, California, USA. \\ ${ }^{2}$ El Colegio de la Frontera Sur, Unidad San Cristóbal, San Cristóbal de Las Casas, Chiapas, México. \\ ${ }^{3}$ Departamento de Botánica, Instituto de Biología, Universidad Nacional Autónoma de México, Ciudad de México, México \\ *Author for correspondence: ohinojosa@ucdavis.edu
}

\begin{abstract}
Background: Dichrocephala is an Old-World genus of the tribe Astereae within the family Asteraceae. One species, D. integrifolia, has been recently reported as introduced in the New World from a pair of collections from Guatemala. During field work in the state of Chiapas in southern Mexico, the species was found and collected. This is the first record of both the genus and species in Mexico and the second record for these taxa in the Americas.

Question: Can D. integrifolia occur in more areas in the New World besides those known from Guatemala and Chiapas?

Studied species: Dichrocephala integrifolia

Study site: Mexico, Central America, and the Caribbean.

Methods: An ecological niche model was made and it was projected into the New World.

Results: The ecological niche model predicts the records of $D$. integrifolia in the New World in addition to other ecologically suitable areas, mostly in pine-oak forests in Mexico and Central America and zones with humid mountain and pine forest in the Caribbean. Moreover, a morphological description and illustrations of the species are provided to help with its identification.

Conclusions: It is desirable to avoid the further spreading of D. integrifolia in the New World. Although this species is not considered as invasive, it seems to have a high dispersal potential and the ecological niche modelling indicates larger regions in the Americas that might be affected.
\end{abstract}

Key words: Ecological niche modeling, exotic plants, flora of Chiapas, Grangeinae, weeds

\section{Resumen}

Antecedentes: Dichrocephala es un género del Viejo Mundo de la tribu Astereae de la familia Asteraceae. Una especie, D. integrifolia, ha sido recientemente reportada como introducida en el Nuevo Mundo de un par de recolectas de Guatemala. Durante trabajo de campo en el estado de Chiapas en el sur de México se encontró y recolectó $D$. integrifolia. Este es el primer registro tanto para el género como para la especie en México y el segundo registro de estos taxones en América.

Pregunta: ¿Puede ocupar D. integrifolia más áreas en el Nuevo Mundo además de las conocidas en Guatemala y Chiapas?

Especies de estudio: Dichrocephala integrifolia

Sitio: México, Centroamérica y el Caribe.

Métodos: Se generó un modelo de nicho ecológico de D. integrifolia en el Viejo Mundo y se proyectó al Nuevo Mundo.

Resultados: El modelo de nicho ecológico elaborado predice los registros de D. integrifolia en el Nuevo Mundo, además de otras áreas ecológicamente idóneas, la mayoría en bosques de pino-encino en México y Centroamérica y zonas con bosque húmedo de montaña y pino en el Caribe. Además, se proporciona una descripción de la morfología e ilustraciones de la especie para ayudar en su identificación.

Conclusiones: Esta especie parece tener un alto potencial de dispersión y el modelo de nicho ecológico indica grandes regiones del Nuevo Mundo que pueden ser afectados.

Palabras clave: Flora de Chiapas, Grangeinae, malezas, modelo de nicho ecológico, plantas exóticas.

This is an open access article distributed under the terms of the Creative Commons Attribution License CCBY-NC (4.0) international. https://creativecommons.org/licenses/by-nc/4.0/ 
Dichrocephala L'Hér. ex DC., is a small Old World genus of the family Asteraceae. The genus belongs to the tribe Astereae, which is the second largest tribe of the family (Brouillet et al. 2009). Members of this tribe have alternate leaves, anthers with lanceolate apical appendages, and style branches mostly with tapering appendages that are dorsally hispidulous, among other features. The tribe is worldwide in distribution, although it is most diverse in the temperate regions. It is well-developed in North America (USA and Canada), where it is represented by 77 genera and 705 species (Spellenberg \& Zucker 2019). In Mexico, the tribe comprises 52 genera and 380 species (Villaseñor 2018), of which only Bellis perennis L. and Symphyotrichum novibelgii (L.) G.L. Nesom were considered as exotic to the flora of Mexico (Villaseñor et al. 2013b).

Within the tribe Astereae, Dichrocephala has been classified in the subtribe Grangeinae (Nesom \& Robinson 2007, Pruski 2011). As treated by (Nesom \& Robinson 2007) this subtribe is predominantly African, with some genera occurring in Asia, one genus in Australia, and two genera in the New World. However, Brouillet et al. (2009) found this group was polyphyletic based on ITS and indicated the need to remove the non-African genera for a monophyletic circumscription of the subtribe. The New World genera that Nesom \& Robinson (2007) included in Grangeinae were Egletes Cass., which is found from the Neotropics to southwestern USA, and Plagiocheilus Arn. ex DC., which occurs in South America. Recently, Pruski (2011) reported the occurrence of Dichrocephala integrifolia (L. f.) Kuntze in Guatemala as an exotic new genus and species of Grangeinae in the New World.

Dichrocephala is native to Africa, Madagascar, Indonesia, and tropical and southwestern Asia (Nesom \& Robinson 2007). The genus comprises three species of annual herbs, which have small, globose, disciform heads and obovate compressed achenes with 1 to few deciduous bristles or without a pappus (Pruski 2011, 2018). According to Nesom \& Robinson (2007) and Pruski (2011), the disciform heads in Dichrocephala consist of numerous marginal pistillate flowers disposed in several series, and less numerous perfect disk flowers, which have yellow or reddish, campanulate or sometimes salverform corollas, with 4-5 lobes. Dichrocephala integrifolia is native to Africa and Asia, but it has been introduced in Europe, Australia, and Guatemala, and it is expected to become naturalized in Central America and the Antilles (Pruski 2018). The species can be recognized from others in the genus mostly by having lyrate-pinnatifid leaves (Pruski 2011, Chen \& Brouillet 2011).
During field work in the state of Chiapas in southern Mexico we found and collected Dichrocephala integrifolia. The species was found on wet trails and near crop plantings in disturbed humid mountain forest. Our collections of D. integrifolia represent the first report of this genus and species for Mexico, and the second report of these taxa in the New World. To estimate the regions in Mexico, Central America, and the Caribbean, which may have suitable ecological conditions for $D$. integrifolia, we implemented ecological niche modelling. We also provide a morphological description and illustrations to help identify the species.

\section{Materials and methods}

The collections of $D$. integrifolia were made in the municipality of Tenejapa, which is in the region known as the Highlands of Chiapas (Villaseñor et al. 2013a). A single collection was made in November 2019 and was keyed to species using Pruski (2018). Additional specimens almost at the same locality (ca. $500 \mathrm{~m}$ away) with several duplicates were collected in January 2020. The specimens were deposited in the National Herbarium of Mexico (MEXU) and in the herbarium of El Colegio de la Frontera Sur $(\mathrm{CH})$ (additional duplicates to be distributed).

Ecological niche modeling. Records of D. integrifolia in the Global Biodiversity Facility (GBIF 2020) were downloaded. The records that represented collections of the species in native locations in the Old World were used to generate the model of ecological niche. A total of 312 georeferenced records from Africa and Asia were used, plus the four adventive records from the New World, i.e., the two collections from Chiapas, Mexico, and the two reports from Guatemala (Pruski 2011, 2018). The model was generated using the Wallace platform (Kass et al. 2018), in which the 312 records were reduced to 280 through the module SpThin (Aiello-Lammens et al. 2015) by applying a distance of $5 \mathrm{~km}$ (Baldwin 2009). The 280 filtered records were modelled on Maxent using 19 bioclimatic variables at 30 seconds of resolution obtained from WorldClim 2 (Fick \& Hijmans 2017). A mask related to the countries with native records of the species was implemented. Several models employing all combinations of feature classes and regularization multiplier values were made to select the most appropriate model (Morales et al. 2017). The model with a feature class of Linear-Quadratic-Hinge (LQH), and a regular- 
ization multiplier value of 3.0, was chosen based on the Akaike information criterion (Warren \& Seifert 2011). To ascertain that the projection of the selected model was implemented correctly a partition of the records was made. This was achieved by using a special partition implementing the Checkerboard type with an aggregation factor of 2 (Peterson et al. 2007, Muscarella et al. 2014). The model was projected for Mexico and Guatemala to determine whether it would predict the four recorded collections from this region. No cutoff threshold was used and the complete logistic output of the model is shown, in order to allow visualization of all zones with environmental suitability for the models.

Taxonomy. The morphology of the species was also examined in the herbaria using dissection microscope to make a morphological description of the species. Pictures of the habitat and habit of the species were taken in the field. A more detailed account of the morphology and synonymy of the species and genus can be found in Pruski (2011).

\section{Results}

With an AUC of 0.902 the implemented model yields a high prediction for the occurrence of Dichrocephala integrifolia in their native Africa and Asia (Figure 1). Likewise, the projection for Mexico and Guatemala correctly predicts the four records currently known from this region (Figure 2). The model also shows the areas that are the most ecologically suitable for the species. In Mexico, these regions are the Mexican Transvolcanic Belt, all Sierras Madres (south, western, and eastern), the Highlands of Chiapas, and the Soconusco region, also in Chiapas. The Mexican states that have most suitable ecological conditions for the species are Mexico City, Tlaxcala, State of Mexico, Puebla, and Hidalgo (Figure 2). The only Mexican states in which the model does not project any surface are those of the Yucatan peninsula (Campeche, Quintana Roo, Yucatan) and the adjacent state of Tabasco. In Guatemala, the entities with the highest putative affected areas are Sacatepequez, Sololá, Totonicapán, Baja

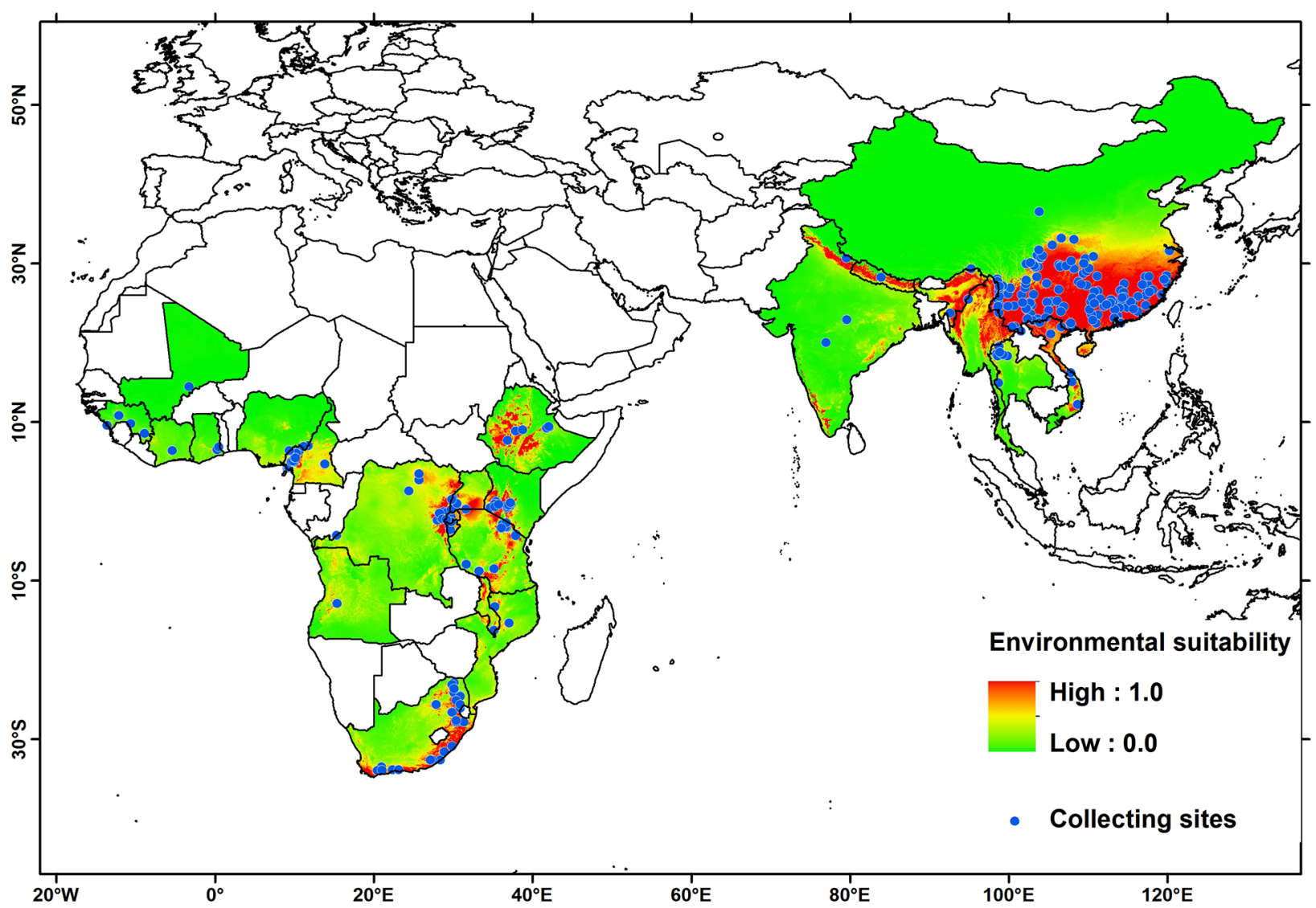

Figure 1. Ecological niche model of Dichrocephala integrifolia in countries of Africa and Asia, where the species is native. Blue points represent collecting sites. 


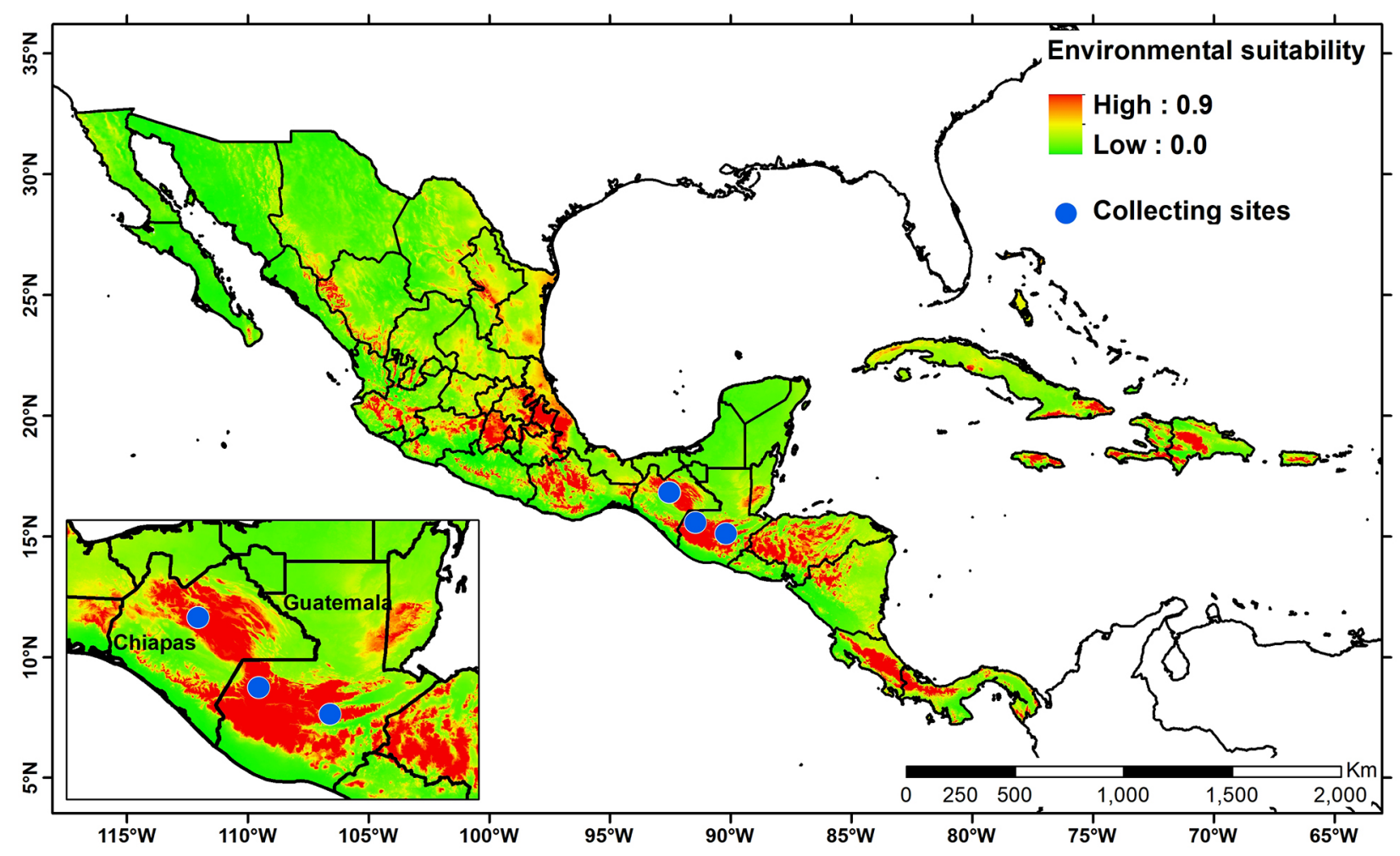

Figure 2. Ecological niche model of Dichrocephala integrifolia in Mexico, Central America, and the Caribbean. The map shows the records from Chiapas, Mexico, and Guatemala. The two records from Mexico appear as a single point due to its proximity. The record from the Sierra Los Cuchumatanes reported in Pruski (2011) has no coordinates and due to this the dot in the map is the centroid for this area with coordinates $91.443951^{\circ} \mathrm{W}$ and $15.583357^{\circ} \mathrm{N}$.

Verapaz, and Chimaltenango. The model also predicts considerable potentially affected areas in Costa Rica, Panama, and Honduras, and smaller regions in Nicaragua, Belize, and El Salvador. In the Caribbean, the model predicts affected regions in Dominican Republic, Haiti, Jamaica, Cuba, and Puerto Rico (Figure 2). Considering the ecoregions of the WWF (Olson et al. 2001) the model indicates that the pine and pine-oak forest might be the most affected communities in Mexico and Guatemala (67\%), and in the Caribbean, both the humid forest and pine forest might be more suitable for $D$. integrifolia.

Taxonomy. Dichrocephala integrifolia (L. f.) Kuntze, Revis. Gen. Pl. 1: 333. 1891. Hippia integrifolia L. f., Suppl. Pl. 389. (1782). = Dichrocephala latifolia DC.

Erect annual herbs, $30-70 \mathrm{~cm}$ high, with tap roots, moderately to scarcely pilose to hirsutulous, the hairs often adpressed. Leaves alternate, lyrate-pinnatifid to simple, petiolate, blades 3-10 $\times 2-6.5 \mathrm{~cm}$, with 3-5 lobes, the apical one larger, ovate to subcordate, 2.5-8 $\times 1.5-5$ $\mathrm{cm}$, palmately veined, the lower lobes often reduced to absent, lobe margins serrate, petioles $0.9-4 \mathrm{~cm}$ long. $\mathrm{Ca}-$ pitulescence cymose paniculiform. Heads small, ovoid to subglobose, peduncles $1.5-3 \mathrm{~mm}$ long, heterogamous, disciform; involucre saucer-shaped, $1 \times 3 \mathrm{~mm}$, phyllaries biseriate, equal or subequal in length, lanceolate, green. Peripherical flowers numerous $(80+)$, in 6-8 series, pistillate and fertile, corollas white, tubular, $0.4-0.5 \mathrm{~mm}$, with 4 apical lobes. Disk flowers 12-16, perfect, fertile, corollas green to yellowish, campanulate, with a short tube and four apical lobes, $0.8-1.0 \mathrm{~mm}$, with few resinous dots, anthers brown, style with two extremely short deltoid branches. Cypselae obovate to oblanceolate, 1.0$1.2 \times 0.4 \mathrm{~mm}$, compressed, greenish to pale brown, with glands near apex, somewhat glutinous, pappus absent or of 1-2 readily deciduous, white bristles, $0.4 \mathrm{~mm}$ long. Receptacle convex-columnar. (Figures $\underline{3}-\underline{6}$ ).

An Old World species native to tropical Africa and Asia, introduced into Europe, SW Asia (Azerbaijan, Georgia, Turkey), Australia, Pacific Islands, and in the New World (Chen \& Brouillet 2011, Pruski 2011, 2018). In the Americas it was previously known from Guatemala (Pruski 2011, 2018), and is here reported from the adjacent state of Chiapas, in southern Mexico. Medicinal uses (indiges- 


\section{Dichrocephala integrifolia in Mexico}

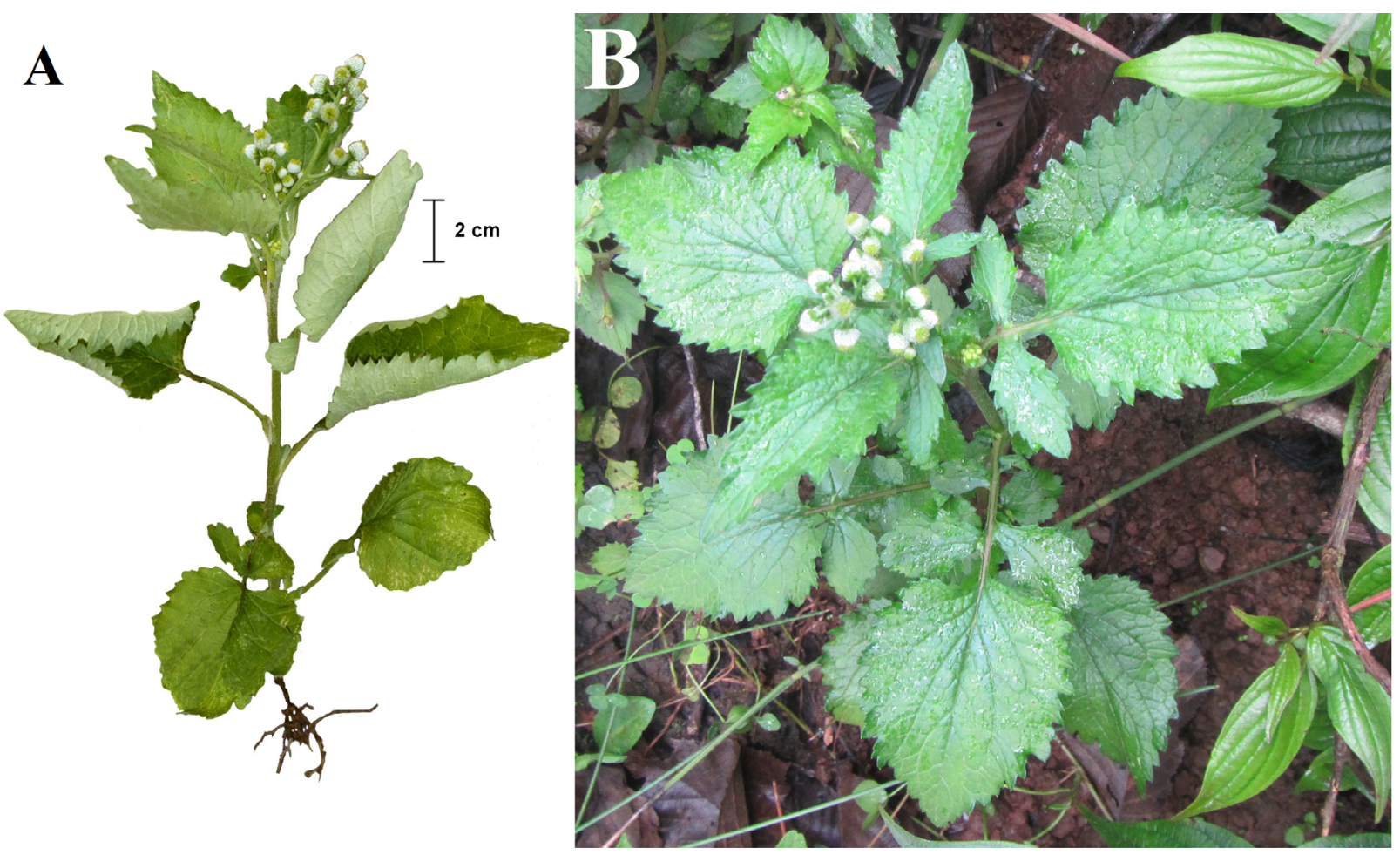

Figure 3. A. Young blooming plants of Dichrocephala integrifolia. B. Note variation from simple to lyrate-pinnatifid leaves.

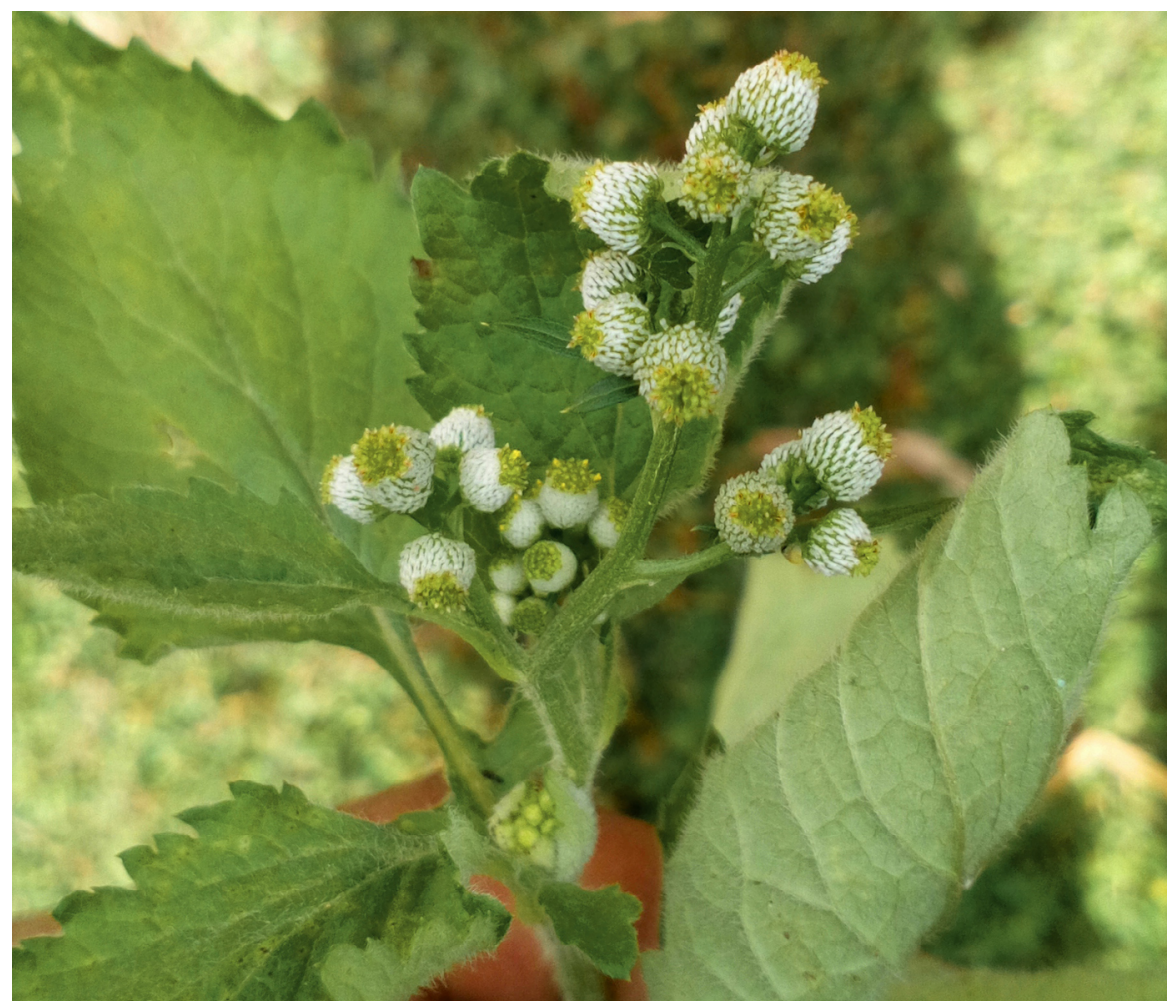

Figure 4. Disciform heads of Dichrocephala integrifolia. Note numerous outer pistillate flowers with white tubular corollas disposed in several series and less numerous central hermaphrodite disk flowers with yellowish-green corollas. 


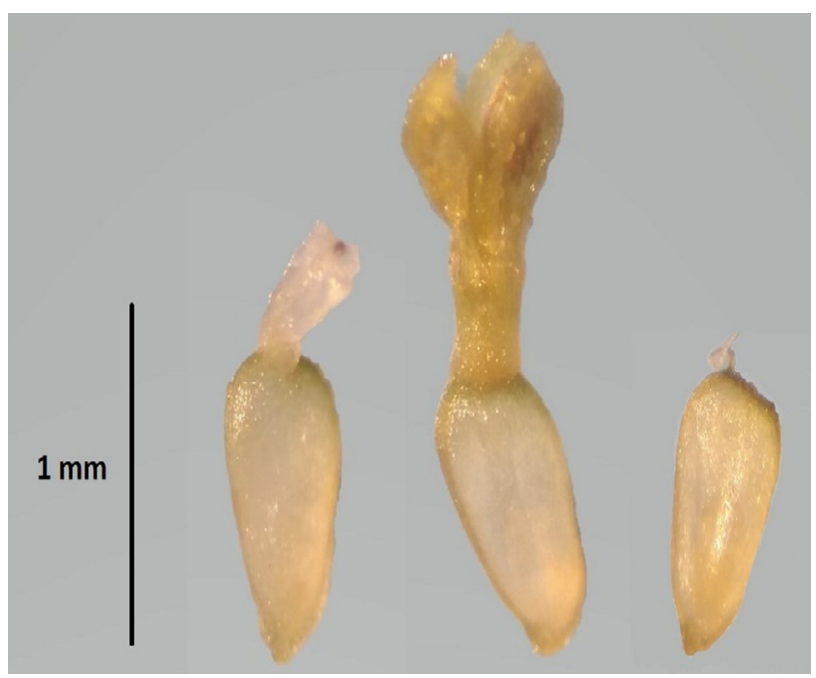

Figure 5. Peripherical flower (left), disk floret (center), and disk cypsela (left) of Dichrocephala integrifolia. Note more campanulate corolla of the disk flower and one slender pappus bristle in the cypsela at the left.

tion, anti-inflammatory, and antiemetic) are reported from China (Chen \& Brouillet 2011).

Habitat in Mexico. Wet and shady trail sides, near small streams and crops in shady hillsides of disturbed humid mountain or pine-oak forests, with Pinus tecunumanii F. Schwerdtf. ex Eguiluz \& J.P. Perry, Quercus sp., Alnus acuminata Kunth, Montanoa hexagona B.L. Rob. \& Greenm., Sambucus nigra L., Cornus excelsa Kunth, Crataegus pubescens (C. Presl) C. Presl, Equisetum hyemale L., and Plantago australis Lam. (Figure 7).

Elevation in Mexico. 2,057-2,200 m.

Specimens examined. Mexico, Chiapas: $1.9 \mathrm{~km}$ NE of Tenejapa, on a wet trail side, $16^{\circ} 49^{\prime} 24^{\prime \prime} \mathrm{N}, 92^{\circ} 31^{\prime} 17^{\prime}$ W, 2,083 m, Nov-13-2019, Oscar Hinojosa-Espinosa \# 734, Mario Ishiki, \& Alfonso Luna (MEXU); $1.7 \mathrm{~km} \mathrm{NE} \mathrm{de}$ Tenejapa, shady and wet sites on hillside near crops of corn, bean, and squashes, $16^{\circ} 49^{\prime} 21^{\prime \prime} \mathrm{N}, 92^{\circ} 31^{\prime} 01^{\prime \prime} \mathrm{W}, 2,057$ m, Jan-20-2020, Mario Ishiki \# 3675, Henry Castañeda, Alfonso Luna, Mario Sánchez-Gutiérrez, \& Erick A. Luna ( $\mathrm{CH}, \mathrm{MEXU}$, and several duplicates to be distributed).

\section{Discussion}

The fact that the selected model of ecological niche correctly predicts actual collections of Dichrocephala integrifolia in Africa and Asia, and the currently known occur- rences in the Americas, suggests that the model is accurate and reliable. According to the model, the Mexican states with more suitable set of conditions for the species are in the mountainous regions with pine, pine-oak, and humid mountain forests. They are among the states with a higher density of alien plant species (Villaseñor \& EspinosaGarcía 2004), except for the state of Tlaxcala. Indeed, the state of Chiapas, in which the species was collected, is the state with the second highest density of alien species in Mexico (Villaseñor \& Espinosa-García 2004). Most of the exotic plant species in Mexico arrived from the Old World (Villaseñor \& Espinosa- García 2004) as is the case for Dichrocephala integrifolia.

It is unclear from where and how this species was introduced into the New World. Pruski (2011) suggested that the species could have been introduced from Africa, based on its apparent restriction to the Atlantic watershed in Guatemala, although he did not discard the possibility of a long dispersal from Asia, or as a result of anthropogenic activities. It seems somewhat difficult that the small cypselae can survive such long dispersals through sea water; however, some physiological related investigations may shed light on it. Therefore, we find more likely that the species was accidentally carried into the New World by people, as the rise of human movement has increased the opportunities for species transportation to novel sites ( $\mathrm{Pe}-$ terson 2003). Such diminutive cypselae (1-1.2 mm, Figure 5) might be inadvertently carried (e.g., in a goods shipped, in the groove of a sole shoe, a bag pack, etc.). Moreover, as discussed above, D. integrifolia has affinities for human disturbed places (e.g., trails, crops, roadsides) both in its native and non-native distribution range (Figure 7).

Pruski (2018) expected that $D$. integrifolia would become naturalized in the Antilles and Central America, following the pattern of other exotic asters in Guatemala, which were presumably introduced into the New World from Africa. Although the species has not been found in these regions yet, our model strongly predicts areas in both the Caribbean and Central America that are environmentally appropriate for $D$. integrifolia supporting the hypothesis of Pruski (2018). We also expect the species to become naturalized and more widespread in Mexico based on the results of the ecological niche model and on its weedy behavior. In west tropical Africa, where the species is native, it is regarded as a high ground weed (Hutchinson \& Dalziel 1963). In China, D. integrifolia is reported from a variety of habitats including meadows, slopes, shaded valleys, but also from altered habitats, such as trails and roadsides (Chen \& Brouillet 2011). 


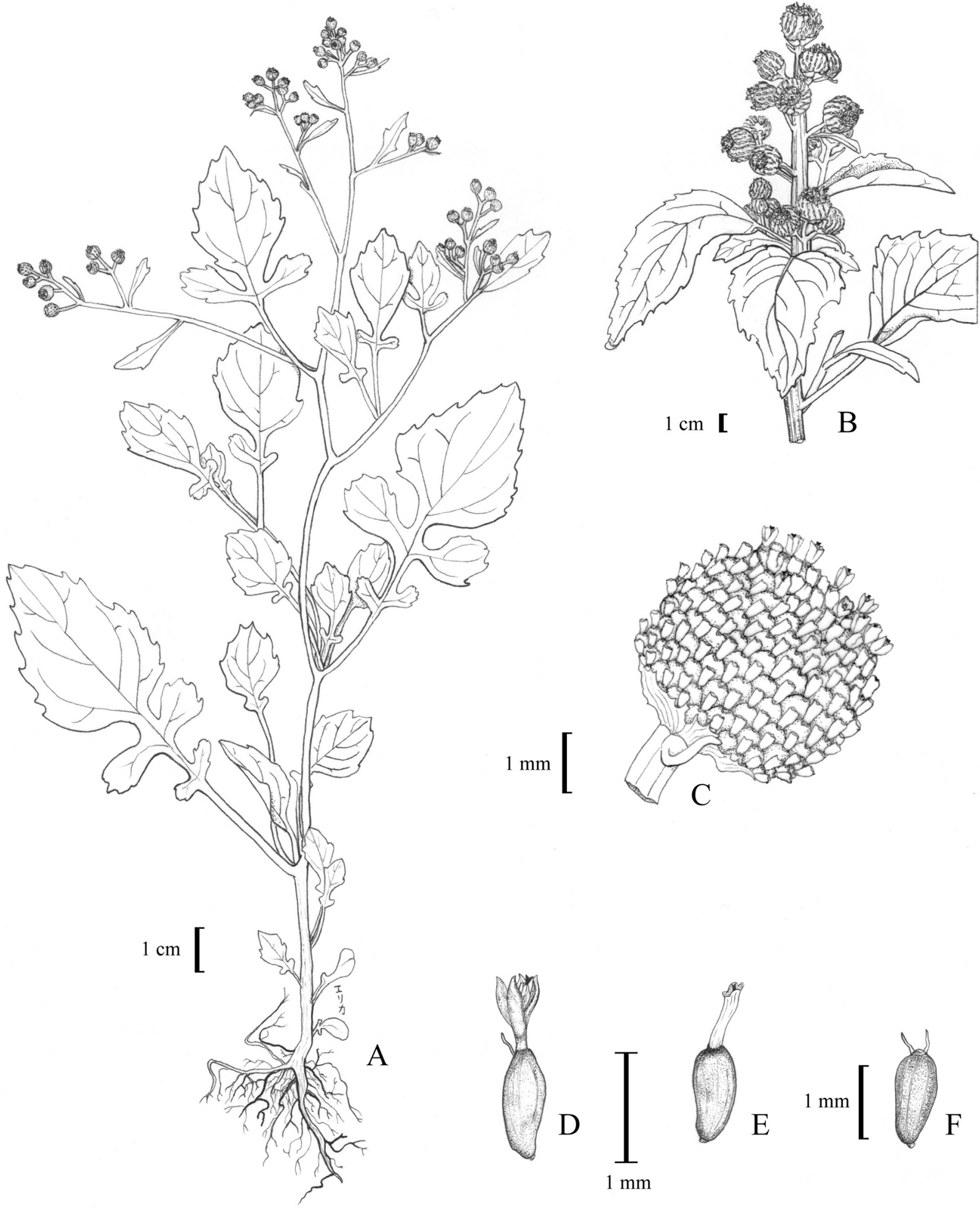

Figure 6. A. Dichrocephala integrifolia, young blooming plant. B. Capitulescence. C. Disciform head. D. disk flower. E. Peripheral pistillate flower. F. Cypsela. 


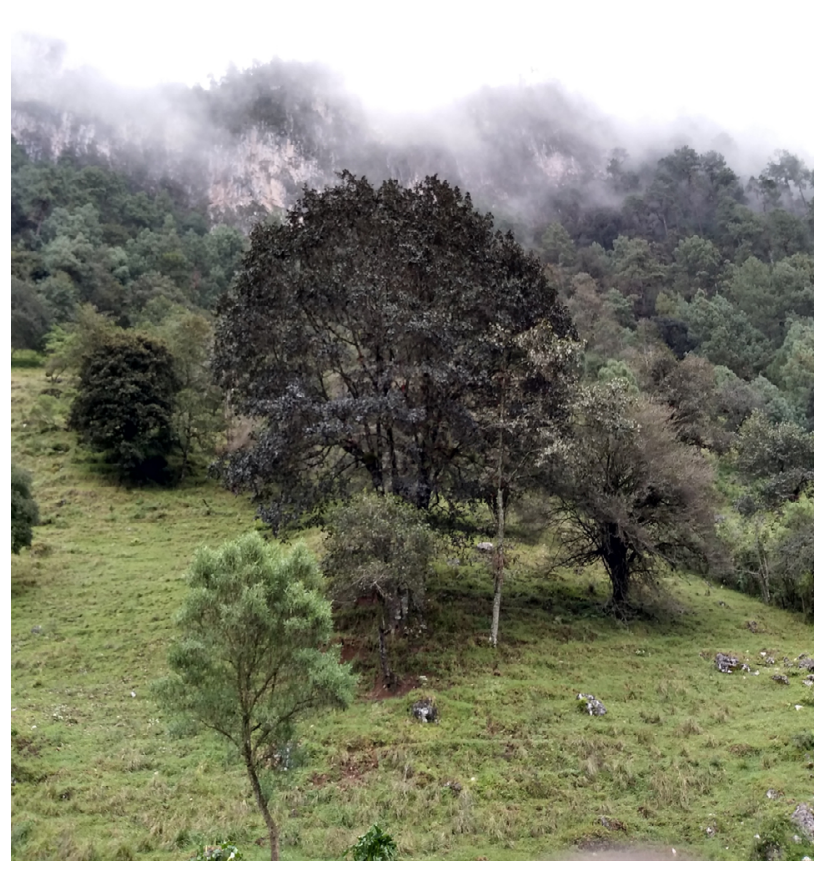

Figure 7. Local environment where Dichrocephala integrifolia was collected in the municipality of Tenejapa, Chiapas, southern Mexico.

It is unknown how long the species has been dwelling in Chiapas. This state is one of the most biodiverse of Mexico: it harbors some 1,912 and 8,790 native genera and species of plants, respectively (Villaseñor 2016). Even though $D$. integrifolia has not been considered a noxious weed, an effort to avoid its continuing expansion and further introductions would be desirable, because weeds might have a negative impact on the native flora, and/or local natural ecosystems and agroecosystems (Villaseñor et al. 2013b). We hope this contribution will provide useful information to help identify $D$. integrifolia as well as the regions in which the species might be present, and therefore, help to monitor its spread and develop strategies to prevent further introductions.

\section{Acknowledgements}

We thank Henry Castañeda, Alfonso Luna, Mario SánchezGutiérrez, and Erick A. Luna for his field assistance. Erika Pérez-Parra and Hiromi Ishiki produced the illustration.

\section{Literature cited}

Aiello-Lammens ME, Boria RA, Radosavljevic A, Vilela B, Anderson RP. 2015. spThin: A R package for spatial thinning of species occurrence records for use in ecological niche models. Ecography 38: 541-545. DOI: https://doi.org/10.1111/ecog.01132

Baldwin RA. 2009. Use of maximum entropy modeling in wildlife research. Entropy 11: 854-866. DOI: https:// doi.org/10.3390/e11040854

Brouillet L, Lowrey TK, Urbatsch L, Karaman-Castro V, Sancho G, Wagstaff S, Semple JC. 2009. Astereae. In: Funk VA, Susanna A, Stuessy TF, Bayer RJ, eds. Systematics, Evolution and Biogeography of Compositae. Vienna: IAPT, pp. 589-629. ISBN: 9783950175431

Chen Y. Brouillet L. 2011. Dichrocephala. In: Wu ZY, Raven PH, Hong DY, eds. Flora of China Volume 2021 (Asteraceae). Beijing-St. Louis, Missouri: Science Press-Missouri Botanical Garden Press, pp. 550-551. ISBN: 9781935641070

Fick SE, Hijmans RJ. 2017. WorldClim 2: new 1-km spatial resolution climate surfaces for global land areas. International Journal of Climatology 37: 4302-4315. DOI: https://doi.org/10.1002/joc.5086

GBIF [Global Biodiversity Facility]. 2020. GBIF Occurrence Download DOI: https://doi.org/10.15468/ dl.8bxrri (Accessed June 29, 2020)

Hutchinson J, Dalziel JM. 1963. Dichrocephala. In: Hepper FN, ed. Flora of West Tropical Africa, Vol II. London: Crown Agents for Overseas Governments \& Administrations, pp. 1354-1355. ISBN: 9780947643751

Kass JM, Vilela B, Aiello-Lammens ME, Muscarella R, Merow C, Anderson RP. 2018. Wallace: A flexible platform for reproducible modeling of species niches and distributions built for community expansion. Methods in Ecology and Evolution 9: 1151-1156. DOI: https:// doi.org/10.1111/2041-210X.12945

Morales NS, Fernández IC, Baca-González V. 2017. MaxEnt's parameter configuration and small samples: are we paying attention to recommendations? A systematic review. PeerJ 5: e3093. DOI: https://doi.org/10.7717/ peerj.3093

Muscarella R, Galante PJ, Soley-Guardia M, Boria RA, Kass JM, Uriarte M, Anderson RP. 2014. ENM eval: An $\mathrm{R}$ package for conducting spatially independent evaluations and estimating optimal model complexity for Maxent ecological niche models. Methods in Ecology and Evolution 5: 1198-1205. DOI: https://doi. org/10.1111/2041-210X.12261

Nesom G, Robinson H. 2007. Tribe Astereae. In: Kubitzki $\mathrm{K}$, ed. The Families and Genera of Vascular Plants, Vol. 8 Flowering plants. Eudicots. Asterales. Berlin: Springer, pp. 284-342. ISBN: 978-3-540-31050-1 


\section{Dichrocephala integrifolia in Mexico}

Olson DM, Dinerstein E, Wikramanayake ED, Burgess ND, Powell GVN, Underwood EC, D’Amico JA, Itoua I, Strand HE, Morrison JC, Loucks CJ, Allnutt TF, Ricketts TH, Kura Y, Lamoreux JF, Wettengel WW, Hedao P, Kassem KR. 2001. Terrestrial ecoregions of the world: a new map of life on Earth. Bioscience 51: 933-938. DOI: https://doi.org/10.1641/00063568(2001)051[0933:TEOTWA]2.0.CO;2

Peterson AT. 2003. Predicting the geography of species' invasions via ecological niche modeling. The Quarterly Review of Biology 78: 419-433. https://doi. org/10.1086/378926

Peterson AT, Papeş M, Eaton M. 2007. Transferability and model evaluation in ecological niche modeling: a comparison of GARP and Maxent. Ecography 30: 550-560. DOI: https://doi.org/10.1111/j.09067590.2007.05102.x

Pruski J. 2011. Studies of Neotropical Compositae-III. Dichrocephala integrifolia (Astereae: Grangeinae) in Guatemala, an exotic genus and species new to the Americas. Phytoneuron 65: 1-9.

Pruski J. 2018. Dichrocephala. In: Davidse G, SousaSánchez M, Knapp S, Chiang-Cabrera F, eds. Flora Mesoamericana. 5(2) Asteraceae. St. Louis Missouri: Missouri Botanical Garden, pp. 608. ISBN: 9780915279982

Spellenberg R, Zucker N. 2019. The sunflower family: A guide to the Family Asteraceae in the Contiguous United States. Sida, Bot. Misc. 52. Forth North, Texas: Botanical Research Institute of Texas. ISBN: 13-978-1889878-65-2

Associate editor: Martha Martínez Gordillo

Author contributions: OHE, DP and MI writing analysis, field work and specimen examination; EO and JLV modeling of potential distribution and writing analysis.
Villaseñor JL. 2016. Checklist of the native vascular plants of Mexico. Revista Mexicana de Biodiversidad 87: 559-902. DOI: http://dx.doi.org/10.1016/j. rmb.2016.06.017

Villaseñor JL. 2018. Diversidad y distribución de la familia Asteraceae en México. Botanical Sciences 96: 332-358. DOI: http://dx.doi.org/10.17129/ botsci. 1872

Villaseñor JL, Espinosa-García FJ. 2004. The alien flowering plants of Mexico. Diversity and Distributions 10: 113-123. https://doi.org/10.1111/j.13669516.2004.00059.x

Villaseñor JL, Ortiz E, Beutelspacher CR, Gómez-López JA. 2013a. La familia Asteraceae en el municipio de San Cristóbal de Las Casas, Chiapas, México. Lacandonia 7: 31-55.

Villaseñor JL, Ortiz E, Hinojosa-Espinosa O, SeguraHernández G. 2013b. Especies de la familia Asteraceae exóticas a la flora de México. México, DF: Secretaría de Agricultura, Ganadería, Desarrollo Rural, Pesca y Alimentación, Servicio Nacional de Sanidad, Inocuidad y Calidad Agroalimentaria, Consejo Nacional Consultivo Fitosanitario, Instituto de Biológia de la Universidad NacionalAutónoma de Méxicoy Asociación Méxicana de la Ciencia de la Maleza.

Warren DL, Seifert SN. 2011. Ecological niche modeling in Maxent: the importance of model complexity and the performance of model selection criteria. Ecological applications 21: 335-342. DOI: https://doi. org/10.1890/10-1171.1 